\title{
Charge properties of peptides derived from casein affect their bioavailability and cytoprotection against $\mathrm{H}_{2} \mathrm{O}_{2}$-induced oxidative stress
}

\author{
Bo Wang, ${ }^{* 1}$ Ningning Xie, $\dagger^{1}$ and $\mathrm{Bo} \mathrm{Li}{ }^{*} \ddagger^{2}$ \\ ${ }^{*}$ College of Food Science and Nutritional Engineering, China Agricultural University, Beijing, 100083, China \\ †Institute of Agro-food Science and Technology, Anhui Academy of Agricultural Sciences, Hefei, 230031, China \\ †Beijing Higher Institution Engineering Research Center of Animal Product, Beijing, 100083, China
}

\begin{abstract}
The effects of charge properties of casein peptides on absorption stability, antioxidant activity, and cytoprotection were evaluated. Alcalase hydrolysates of casein were separated into 4 fractions by cation-exchange chromatography according to charge properties. After simulated digestion and Caco-2 cell transmembrane transport, we determined the total antioxidant capacity (Trolox equivalent antioxidative capacity and oxygen radical antioxidant activity) and nitrogen content of peptide fractions to estimate available antioxidant efficacy and bioavailability (BA) of peptides. Results showed that negatively charged peptide fractions had greater BA and antioxidant activities after digestion and absorption. The peptide permeates were used to test the cytoprotective effect against $\mathrm{H}_{2} \mathrm{O}_{2}$-induced oxidative damage in HepG-2 cells. All peptide permeates increased cell viability, elevated catalase activity, and decreased superoxide dismutase activity. However, negatively charged peptide fractions preserved cell viability to a greater degree. Therefore, the negatively charged peptides from casein may be potential antioxidants and could be used as ingredients in functional foods and dietary supplements.
\end{abstract}

Key words: casein, charge property, antioxidative peptide, bioavailability, HepG-2 cells

\section{INTRODUCTION}

Casein is the main proteinaceous ingredient of milk, where it accounts for $80 \%$ of total protein. Digestion of casein yields physiologically important bioactive peptides, which play an important role in the nervous, cardiovascular, digestive, and immune systems (Kitts, 2005; Silva and Malcata, 2005). Researchers are becoming interested in various peptides within the casein

Received June 29, 2015.

Accepted December 15, 2015.

${ }^{1}$ These authors contributed equally to this research.

${ }^{2}$ Corresponding author: libo@cau.edu.cn system, such as antioxidant peptides (De Gobba et al., 2014), angiotensin-converting enzyme (ACE) inhibitory peptides (Contreras et al., 2009), immunomodulatory peptides (Malinowski et al., 2014), and metal-chelating peptides (Jiang et al., 2014).

Casein-derived peptides can be used as a basic compound of functional foods, nutraceuticals, and dietary supplements because of their health benefits and safety (Kitts, 2005; Kim et al., 2007; Sarmadi and Ismail, 2010). However, one of the greatest challenges when developing functional foods is proving the in vivo efficacy of their bioactive components. The gastrointestinal (GI) tract is a major barrier in the human body. To exert their biological activity, bioactive compounds have to cross the GI barrier and reach the circulation and target sites in an active form (Vermeirssen et al., 2002; Regazzo et al., 2010).

In vitro methods to simulate the human digestive tract are extensively used because they are rapid, safe, and do not have the same ethical restrictions as in vivo methods (Sannaveerappa et al., 2007; Cinq-Mars et al., 2008). These methods have been used to test Maillard products (Tagliazucchi et al., 2010) and protein hydrolysates (You et al., 2010; Chen and Li, 2012). However, most studies have been conducted to evaluate the activity and fate of an antioxidant in the human upper digestive system, whereas relatively few studies have assessed human intestinal absorption. Studies of the bioavailability (BA) of antioxidative peptides have been carried out on synthesized peptides (Vij et al., 2016) and protein hydrolysates (You et al., 2010; Orsini Delgado et al., 2011) and these peptides exhibited good tolerance to GI digestion. Furthermore, Chen and $\mathrm{Li}$ (2012) reported that the casein-derived peptides $<1,000$ Da exhibited the best initial and surviving antioxidant activities. Picariello et al. (2010) reported that peptides containing more neutral and basic AA underwent faster degradation compared with those with more acidic AA. Savoie et al. (2005) observed that peptides rich in proline and glutamic acids are more resistant to pepsin and pancreatin activity. Burrell (1993) reported that peptides with the C-terminal end of lysine and arginine are 
preferentially cleaved by trypsin. In short, these studies indicated that molecular weights, AA composition, and AA sequence of peptides affected resistance to pepsin and trypsin. In our previous work (Ao and $\mathrm{Li}, 2013$ ), we studied the GI digestion stability of casein-derived peptides with different charge properties. Our results showed that the negatively charged fraction, which contains more acidic AA, possessed better digestive stability. However, absorption stability and activity of the peptide permeates have not been further investigated.

Caco-2 cells derived from a human intestinal adenocarcinoma have recently been found to provide a useful cell culture model of the small intestinal epithelium. The Caco-2 cell line exhibits spontaneous enterocytelike differentiation under standard culture conditions, showing morphological polarity and expressing brushborder hydrolases (Shimizu et al., 1997). Recently, 2 models including simulated gastrointestinal digestion and Caco-2 cell monolayer were used to simulate the digestion of GI tract and absorption of the small intestinal epithelium (Samaranayaka et al., 2010; Xie et al., 2013). These methods were applied to study the BA of casein-derived peptides with different charges in the present work.

Cellular antioxidant efficacy of casein hydrolysates has been reported by Kim et al. (2007). García-Nebot et al. (2011) reported that caseinophosphopeptides showed cytoprotective effects against $\mathrm{H}_{2} \mathrm{O}_{2}$-induced oxidative stress in Caco-2 cells by preserving cell viability, increasing glutathione (GSH) content, inducing catalase enzyme activity, and diminishing lipid peroxidation. Xie et al. (2013) adopted an oxidative damage model of HepG-2 cells to evaluate cellular antioxidant efficacy of casein peptides. The results showed that alcalase hydrolysates exerted stronger potential on BA and in vitro antioxidant efficacy compared with GI digests. In this study, we adopted the oxidative damage model of HepG-2 cells to evaluate the cellular antioxidant efficacy of peptides surviving simulated digestion and absorption.

Therefore, the present study was carried out to investigate the change in antioxidant activities of casein peptides with different charges during simulated GI digestion and absorption, to estimate the effect of charge properties of peptides on BA, and to further evaluate the antioxidant efficacy of the peptide permeates.

\section{MATERIALS AND METHODS}

\section{Materials and Chemicals}

Casein (C3400), alcalase ( $\geq 24,000 \mathrm{U} / \mathrm{g}$; P4860), pepsin $(\geq 250$ units/mg powder; P7000), pancreatin $(4 \times$ USP specification; P1750), 2,4,6-trinitrobenzenesul- fonic acid (TNBS, picrylsulfonic acid solution; P2297), 2,2'-azino-bis(3-ethylbenzothiazoline-6-sulfonic acid) diammonium salt (ABTS, A1888), GSH (G4251), fluorescein (46955), Trolox (238813, 6-hydroxy-2,5,7,8tetramethylchroman-2-carboxylic acid), phenyl isothiocyanate, and trimethylamine were purchased from Sigma-Aldrich Chemical Co. (St. Louis, MO). Dulbecco modified Eagle's minimal essential medium (DMEM), fetal bovine serum (FBS), NEAA, penicillin, streptomycin, Hanks' balanced salts solution (HBSS) and trypsin-EDTA were products of Hyclone (Thermo Scientific, Waltham, MA).

\section{Preparation of Casein Hydrolysates}

Casein was hydrolyzed by alcalase as follows. Aliquots of casein solution (4\%, wt/vol, at $\mathrm{pH} 8.0)$ were hydrolyzed by alcalase $(2 \% \mathrm{wt} / \mathrm{wt})$ at $55^{\circ} \mathrm{C}$ for $4 \mathrm{~h}$. After hydrolysis with shaking, the hydrolysate solution was heated in boiling water for 10 min to inactivate the alcalase, adjusted to $\mathrm{pH} 7.0$ with $0.01 \mathrm{M} \mathrm{HCl}$, and then centrifuged at $8,000 \times g$ for $15 \mathrm{~min}$, and the supernatant was lyophilized for further analysis.

\section{Separation of Peptide Fractions from Casein Hydrolysates}

Lyophilized casein hydrolysates were diluted in buffer A (0.2 $M$ sodium acetate buffer, $\mathrm{pH} 6.0)$. Hydrolysate solution $(200 \mathrm{mg} / \mathrm{mL}, 1.0 \mathrm{~mL})$ was applied to a SPSephadex C-25 (GE Healthcare Life Science, Pittsburgh, PA) cation-exchange column (diameter $2.6 \mathrm{~cm}$ and $20 \mathrm{~cm}$ long) equilibrated by buffer $\mathrm{A}$. The column was eluted with buffer $\mathrm{A}$ from 0 to $80 \mathrm{~min}$, and then a gradient of $\mathrm{NaCl}(0$ to $1 M$ ) from 80 to $180 \mathrm{~min}$. Each fraction was monitored at $220 \mathrm{~nm}$ by the HD-A chromatography data handling system (Shanghai Qingpu Huxi Instruments, Shanghai, China), and the flow rate was controlled at $1 \mathrm{~mL} / \mathrm{min}$. Each fraction was pooled and then concentrated. The $\mathrm{NaCl}$ in fractions was removed by using a 5 -mL D-Salt Excellulose Plastic Desalting Column (Pierce Biotechnology Co., Rockford, IL). Peptide fractions were lyophilized for further analysis.

\section{Amino Acid Composition}

The AA composition of peptide fractions was analyzed according to the method of You et al. (2010). Briefly, the fractions were hydrolyzed with $6 \mathrm{~N} \mathrm{HCl}$ at $110^{\circ} \mathrm{C}$ for $24 \mathrm{~h}$. After precolumn derivatization with phenyl isothiocyanate and triethylamine, AA analysis was conducted on a Shimadzu LC-15C HPLC system (Shimadzu Scientific Instruments, Kyoto, Japan) with a HPLC column (Zorbax SB-C18, $4.6 \mathrm{~mm}$ i.d. $\times 250$ 
mm, $5 \mu \mathrm{m}$ film thickness; Agilent Technologies, Palo Alto, CA) with a linear gradient mixture composed of solvent A (10 mM phosphate buffer, $\mathrm{pH} 6.9$ ) and solvent B (acetonitrile).

\section{Simulated GI Digestion In Vitro}

Simulated GI digestion in vitro of peptide fractions was performed according to a method reported previously (Samaranayaka et al., 2010) with some modifications. Briefly, the peptide dispersion $(40 \mathrm{mg} / \mathrm{mL}, \mathrm{pH}$ 2.0) was hydrolyzed first by pepsin (1:35 wt/wt) at $37^{\circ} \mathrm{C}$ for $2 \mathrm{~h}$, adjusted to $\mathrm{pH} 7.0$, and then pancreatin was added at a ratio of enzyme to substrate of 1:25 (wt/wt). The mixture was further incubated at $37^{\circ} \mathrm{C}$ for another $2 \mathrm{~h}$. At the end of hydrolysis, the hydrolysate solution was heated in boiling water for 10 min to inactivate the enzymes. During the simulated GI digestion, samples were collected every other hour, lyophilized, and stored at $-80^{\circ} \mathrm{C}$ for further analysis.

\section{Caco-2 Cell Culture}

Caco-2 cells were cultured in DMEM supplemented with $10 \%$ FBS, $1 \%$ NEAA, $100 \mathrm{U} / \mathrm{mL}$ penicillin, and $0.1 \mathrm{mg} / \mathrm{mL}$ streptomycin. They were incubated at $37^{\circ} \mathrm{C}$ in a humidified atmosphere of $5 \% \mathrm{CO}_{2}$ in air. The monolayer became confluent 3 to $4 \mathrm{~d}$ after seeding at 1 $\times 10^{6}$ cells/flask, and the cells were subcultured at split ratio of $1: 5$ by trypsinization ( $0.5 \%$ trypsin and $0.05 \%$ EDTA). Caco-2 cells used in this study were between passages 30 and 42 .

For the permeability study, Caco- 2 cells $\left(1 \times 10^{6}\right.$ cells $/ \mathrm{mL}$ ) were seeded onto cell culture inserts (0.4 $\mu \mathrm{m}$ pore size, $4.2-\mathrm{cm}^{2}$ growth surface, Nunc, Thermo Scientific) in a 6 -well culture plate. The medium was changed every other day for at least $21 \mathrm{~d}$ until the Caco-2 cells were fully differentiated. The integrity of the cell layer was evaluated by measuring the transepithelial electrical resistance (TEER) by using a Millicell Voltohmmeter (Millipore Corp., Bedford, MA). Only Caco-2 monolayers showing TEER $>400 \Omega \cdot \mathrm{cm}^{2}$ were used for permeability experiments (Miguel et al., 2008). The integrity of the monolayers was checked before and after the experiment.

\section{Transepithelial Transport Studies}

After TEER measurement, Caco-2 cell monolayers were gently rinsed twice with warmed HBSS ( $\mathrm{pH}$ 7.4), and then $2 \mathrm{~mL}$ of HBSS was added to the apical and basolateral sides. After a 30 -min incubation at $37^{\circ} \mathrm{C}$, the HBSS in the apical side was replaced by an aliquot of $1.2 \mathrm{~mL}$ of GI digest solution $(40 \mathrm{mg} / \mathrm{mL})$ in HBSS.
After incubating at $37^{\circ} \mathrm{C}$ for $120 \mathrm{~min}$, aliquots of the basolateral solutions were taken and lyophilized for further assays. In all cases, solvent blanks were performed.

\section{Determination of Peptide Nitrogen and BA}

Peptide nitrogen (PN) analysis, based on the AA group, was determined by the TNBS method (LiceagaGesualdo and Li-Chan, 1999; Samaranayaka et al., 2010) with some modifications. Briefly, for total N, after acid hydrolysis $\left(6 \mathrm{M} \mathrm{HCl}\right.$ at $110^{\circ} \mathrm{C}$ for $24 \mathrm{~h}$ ), sample $(0.5 \mathrm{mg} / \mathrm{mL}, 10 \mu \mathrm{L})$ was added to $100 \mu \mathrm{L}$ of potassium borate $(0.1 M)$ and $40 \mu \mathrm{L}$ of TNBS $(1.2 \mathrm{mg} / \mathrm{mL})$ in each well of a 96-well plate. After a 1-h incubation at $37^{\circ} \mathrm{C}$ in darkness, absorbance was measured at 405 nm by using a plate reader (Thermo Multiskan MK3; Thermo Scientific). To determine the content of amino nitrogen in free AA, the sample was dissolved in $3.5 \%$ sulfosalicylic acid and centrifuged at $8,000 \times g$ for 10 min. The supernatant was then used for the TNBS assay. The content of PN was calculated as the difference of total $\mathrm{N}$ minus AA-N (expressed as $\mu$ mol of glycine).

The BA of peptide fractions was expressed by the ratio of $\mathrm{PN}$ of permeates to the initial $\mathrm{PN}$ :

$$
\mathrm{BA}=(\mathrm{PPN} / \mathrm{IPN}) \times 100 \%,
$$

where PPN = peptide nitrogen of peptide permeates in the basolateral chamber, and IPN = initial peptide nitrogen added to apical chamber.

\section{Antioxidant Activity Assays}

Trolox Equivalent Antioxidant Capacity. The antioxidant activity of GI digest and the Caco- 2 cell permeates were measured by the ABTS-radical cation decolorization assay using the method described by Samaranayaka et al. (2010). The Trolox equivalent antioxidative capacity (TEAC) was determined and compared with values for a standard curve prepared with Trolox (0 to $300 \mu M$ final assay concentrations). In all cases, the activity of solvent blank was deducted.

Oxygen Radical Antioxidant Capacity. The oxygen radical antioxidant capacity (ORAC) method (Dávalos et al., 2004; Zulueta et al., 2009) using fluorescein as fluorescent probe was applied. The automated ORAC assay was performed in black 96-well plates (Costar, Corning, NY) by using a Tecan Infinite M200 microplate reader as well as Tecan i-Control software (Tecan Inc., Männedorf, Switzerland) with fluorescence filters for an excitation wavelength of 485 $\mathrm{nm}$ and an emission wavelength of $535 \mathrm{~nm}$. The ORAC values were expressed as micromole of Trolox equiva- 
lents (TE) per milligram of lyophilized sample $(\mathbf{L S}$; $\mu \mathrm{mol}$ of $\mathrm{TE} / \mathrm{mg}$ of LS)

\section{Cytoprotective Effect of Peptide Permeates}

The HepG-2 cell model (Yang et al., 1999) was applied with some modifications. Stock HepG-2 cells were cultured in tissue culture flasks $\left(25 \mathrm{~cm}^{2}\right.$, Nunc) in complete medium (DMEM supplemented with $20 \%$ FBS, $100 \mathrm{U} / \mathrm{mL}$ penicillin, and $0.1 \mathrm{mg} / \mathrm{mL}$ streptomycin). For cellular antioxidant activity, HepG-2 cells were seeded $\left(10^{5}\right.$ cells/well) in a 6 -well plate and cultured for $12 \mathrm{~h}$. Then, peptide permeates $(1 \mathrm{mg} / \mathrm{mL})$ in DMEM, $\mathrm{H}_{2} \mathrm{O}_{2}$ in DMEM $(50 \mu M)$, and $\mathrm{H}_{2} \mathrm{O}_{2}$ with peptide permeates in DMEM were added to each well and incubated for another $24 \mathrm{~h}$.

\section{Cell Viability}

The cell viability of HepG-2 was assessed by using the trypan blue dye exclusion method (Wijeratne et al., 2005). The stained (dead) cells and the total cells per square of the board were counted under a microscope (SZ51, Olympus, Tokyo, Japan). The growth percentage of cells cultured without $\mathrm{H}_{2} \mathrm{O}_{2}$-treatment was treated as $100 \%$.

\section{Determination of Cellular Antioxidant Enzymes}

The activity of catalase (CAT) was determined using the method reported by Chen et al. (2012). One unit of CAT was defined as the amount of enzyme that catalyzed decomposition of $1 \mu \mathrm{mol}$ of $\mathrm{H}_{2} \mathrm{O}_{2}$. Superoxide dismutase enzyme (SOD) and glutathione peroxidase (GSH-Px) activities were measured by using commercial kits (Nanjing Jiancheng, China). Enzyme activities were calculated as units per milligram $(\mathrm{U} / \mathrm{mg})$ of protein. The content of protein was detected by using the bicinchoninic acid (BCA) method (Binker et al., 2015).

\section{Statistical Analysis}

All experiments were done in at least triplicate, and the data were expressed as means \pm standard deviations. The statistical differences between results were determined using a one-way ANOVA test (version 13.0, SPSS Inc., Chicago, IL).

\section{RESULTS AND DISCUSSION}

\section{Separation and Characterization of Peptide Fractions}

The column chromatogram of casein hydrolysates on SP-Sephadex C-25 is shown in Figure 1. Four peptide fractions (CE-F1 to CE-F4) were isolated. Positively charged peptides bind well to a negatively charged matrix, which results in the negatively charged peptide fractions being eluted first. With the concentration of $\mathrm{NaCl}$ increasing, fractions with the weakest ionic interactions elute first and those with strong ionic charges are eluted thereafter (Ao and Li, 2013). Therefore, CEF1 and CE-F2, eluted first using sodium acetate buffer (pH 6.0), represented the negatively charged fractions (NCF), and CE-F3 and CE-F4 represented the positively charged fractions (PCF), which were eluted with a linear gradient of $\mathrm{NaCl}$. The AA composition of the 4 peptide fractions was determined by the method of precolumn derivatization (Table 1). Fractions CE-F1 and CE-F2 contained a high content of acidic AA of 29.26 and $27.60 \mathrm{~g} / 100 \mathrm{~g}$ of total AA, respectively. In contrast, CE-F3 and CE-F4 had high contents of basic AA of 37.45 and $41.75 \mathrm{~g} / 100 \mathrm{~g}$ of total AA, respectively.

The antioxidant activities of $\mathrm{NCF}$ and $\mathrm{PCF}$ were determined by TEAC and ORAC assays (Table 2); CE-F1 showed the strongest $(P<0.05)$ antioxidant activities among all fractions.

\section{Changes in PN During Simulated GI Digestion and Caco-2 Cell Transport}

We investigated changes in $\mathrm{PN}$ of $\mathrm{NCF}$ and $\mathrm{PCF}$ during the simulated in vitro GI digestion. As shown in Figure 2A, during the gastric digestion (the first 2 h), PN decreased rapidly for NCF, and the residual rates at 1 and $2 \mathrm{~h}$ were, respectively, 81.5 and $73.5 \%$. In contrast, no obvious change $(P>0.05)$ occurred for PCF. However, during intestinal digestion (latter $2 \mathrm{~h}$ ), PN decreased rapidly for PCF, whereas no obvious change for NCF was observed $(P>0.05)$. These results indicated that the $\mathrm{PCF}$ was resistant to gastric digestion and that the $\mathrm{NCF}$ was resistant to intestinal digestion. Agudelo et al. (2004) reported that after a 6 -h pancreatin hydrolysis of casein, the $\mathrm{N}$ contents in the basic-neutral fraction decreased more rapidly compared with the acid and slightly acid fractions. Changes in PN content are related to the degree of hydrolysis by enzyme degradation. Burrell (1993) reported that trypsin preferentially cleaves peptide bonds with Cterminal Lys and Arg. As shown in Table 1, the PCF contained more Lys and Arg than did the NCF; therefore, NCF was more resistant than PCF to intestinal digestion. Moreover, NCF contained high contents of Pro and Glu, which rendered the NCF resistant to enzyme hydrolysis. Cardillo et al. (2003) and Mizuno et al. (2004) confirmed that Pro-containing peptides were resistant to intestinal proteolysis. Savoie et al. (2005) also observed that peptides rich in Pro and Glu are more resistant to pepsin and pancreatin activity. 
Table 1. Amino acid composition (g/100 g; means \pm SD) of negatively charged and positively charged peptide fractions

\begin{tabular}{|c|c|c|c|c|}
\hline \multirow[b]{2}{*}{ Amino acid } & \multicolumn{4}{|c|}{ Fraction $^{1}$} \\
\hline & CE-F1 & CE-F2 & CE-F3 & CE-F4 \\
\hline Aspartate & $8.51 \pm 0.47$ & $7.31 \pm 0.36$ & $9.09 \pm 0.32$ & $7.45 \pm 0.33$ \\
\hline Glutamate & $20.75 \pm 0.78$ & $20.29 \pm 1.03$ & $6.35 \pm 0.15$ & $4.94 \pm 0.18$ \\
\hline Serine & $6.16 \pm 0.34$ & $5.72 \pm 0.27$ & $4.43 \pm 0.17$ & $4.65 \pm 0.05$ \\
\hline Glycine & $3.83 \pm 0.13$ & $3.23 \pm 0.24$ & $3.04 \pm 0.25$ & $3.87 \pm 0.12$ \\
\hline Histidine & $0.06 \pm 0.02$ & $0.04 \pm 0.02$ & $5.96 \pm 0.13$ & $7.36 \pm 0.14$ \\
\hline Threonine & $5.90 \pm 0.15$ & $6.27 \pm 0.21$ & $2.94 \pm 0.26$ & $3.78 \pm 0.26$ \\
\hline Alanine & $3.20 \pm 0.23$ & $3.04 \pm 0.18$ & $2.44 \pm 0.22$ & $1.59 \pm 0.13$ \\
\hline Proline & $11.05 \pm 0.36$ & $11.79 \pm 0.45$ & $4.27 \pm 0.29$ & $2.79 \pm 0.04$ \\
\hline Arginine & $2.83 \pm 0.12$ & $3.23 \pm 0.15$ & $13.62 \pm 0.18$ & $15.61 \pm 0.32$ \\
\hline Tyrosine & $3.81 \pm 0.22$ & $4.37 \pm 0.14$ & $4.33 \pm 0.21$ & $4.83 \pm 0.11$ \\
\hline Valine & $6.09 \pm 0.39$ & $6.41 \pm 0.21$ & $3.43 \pm 0.11$ & $3.30 \pm 0.24$ \\
\hline Methionine & $2.86 \pm 0.19$ & $3.23 \pm 0.13$ & $1.92 \pm 0.14$ & $1.17 \pm 0.17$ \\
\hline Cysteine & $1.46 \pm 0.14$ & $0.16 \pm 0.17$ & $0.30 \pm 0.08$ & $0.29 \pm 0.04$ \\
\hline Isoleucine & $4.59 \pm 0.21$ & $4.84 \pm 0.33$ & $4.37 \pm 0.19$ & $3.96 \pm 0.19$ \\
\hline Leucine & $7.55 \pm 0.27$ & $7.79 \pm 0.23$ & $7.26 \pm 0.17$ & $7.07 \pm 0.19$ \\
\hline Phenylalanine & $4.50 \pm 0.33$ & $5.13 \pm 0.27$ & $4.48 \pm 0.27$ & $4.85 \pm 0.31$ \\
\hline Lysine & $3.73 \pm 0.11$ & $3.99 \pm 0.19$ & $17.87 \pm 0.37$ & $18.78 \pm 0.22$ \\
\hline Tryptophan & $3.10 \pm 0.31$ & $3.14 \pm 0.21$ & $3.88 \pm 0.28$ & $3.71 \pm 0.18$ \\
\hline Total & 100.00 & 100.00 & 100.00 & 100.00 \\
\hline Total acid AA & 29.26 & 27.60 & 15.44 & 12.39 \\
\hline Total basic AA & 6.62 & 7.26 & 37.45 & 41.75 \\
\hline
\end{tabular}

${ }^{1} \mathrm{CE}-\mathrm{F} 1$ and CE-F2 represent negatively charged peptide fractions eluted by $20 \mathrm{~m} M$ sodium acetate buffer $(\mathrm{pH}$ 6.0); CE-F3 and CE-F4 represent positively charged peptide fractions eluted by using a gradient of $\mathrm{NaCl}(0-1$ $M)$.

Before the transport study, PN contents for the apical and basolateral chambers of the Caco-2 cell model were $0.019 \pm 0.005$ and $0.0099 \pm 0.006 \mu \mathrm{mol}$ of glycine equivalent, which were negligible compared with the $\mathrm{PN}$ of peptide permeates across Caco-2 cells. As shown in Figure 2B, after $1 \mathrm{~h}$ of absorption, the PN content for CE-F1 in the basolateral side was $1.57 \mu \mathrm{mol}$ of glycine equivalent, which was significantly higher than that of the other 3 fractions $(P<0.05)$. At the end of transport, the $\mathrm{PN}$ for all fractions decreased. This decrease in PN may be caused by P-glycoprotein, a plasma membrane-associated energy-dependent efflux pump expressed in the human GI tract (Bodó et al., 2003; Schwab et al., 2003). This efflux protein could

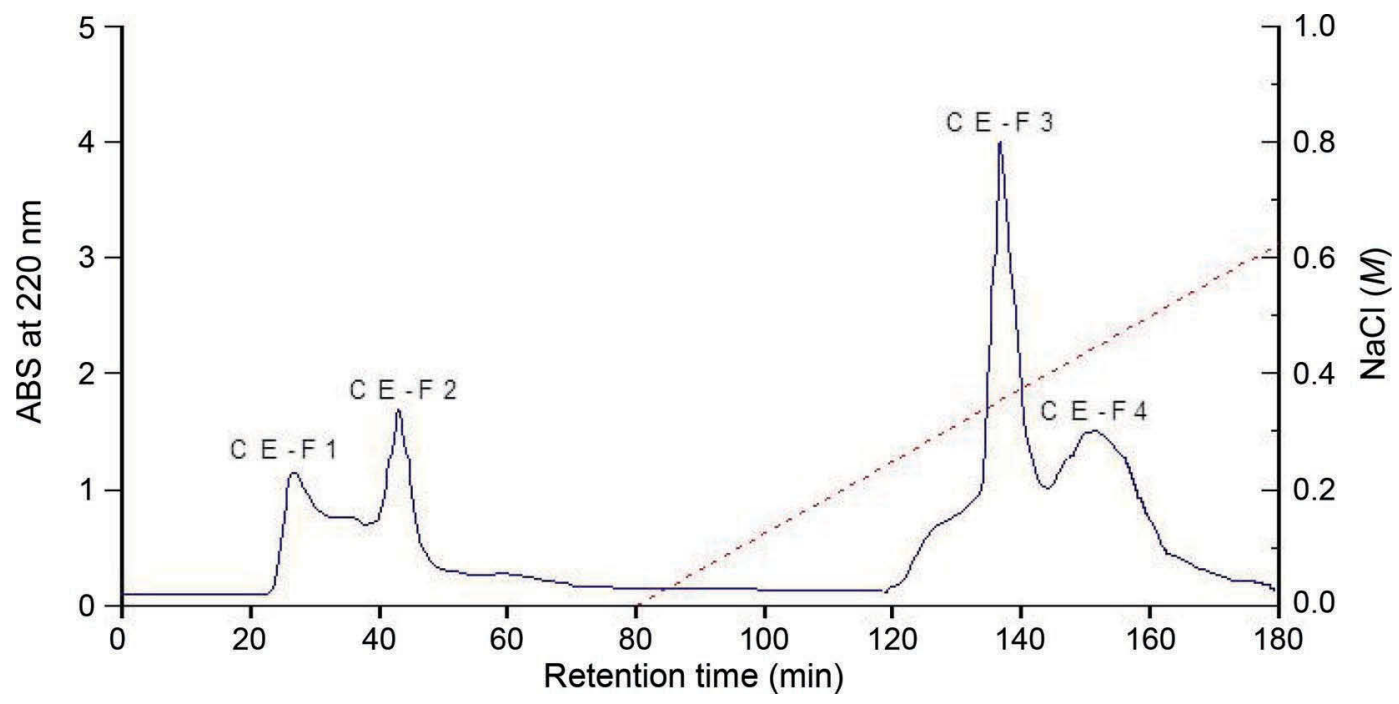

Figure 1. Cation-exchange chromatography (absorbance at $220 \mathrm{~nm}$ ) of casein hydrolysates (CE-F1 to CE-F4). From 0 to 80 min, the elution solvent was $0.2 \mathrm{M}$ sodium acetate buffer ( $\mathrm{pH}$ 6.0), and from 80 to $180 \mathrm{~min}$, the elution solvent was a gradient of $\mathrm{NaCl}(0-1 \mathrm{M}$ ). Color version available online. 
Table 2. Antioxidant activity ${ }^{1}$ of casein-derived peptide fractions by cation-exchange chromatography

\begin{tabular}{lrc}
\hline Peptide fraction & TEAC & ORAC \\
\hline CE-F1 & $314.01 \pm 7.56^{\mathrm{a}}$ & $1.186 \pm 0.047^{\mathrm{a}}$ \\
CE-F2 & $287.34 \pm 12.97^{\mathrm{b}}$ & $1.047 \pm 0.083^{\mathrm{b}}$ \\
CE-F3 & $83.65 \pm 4.97^{\mathrm{c}}$ & $0.660 \pm 0.086^{\mathrm{c}}$ \\
CE-F4 & $35.72 \pm 3.31^{\mathrm{d}}$ & $0.594 \pm 0.057^{\mathrm{c}}$ \\
\hline
\end{tabular}

${ }^{\mathrm{a}-\mathrm{d}}$ Means within a column with different superscript letters differ $(P$ $<0.05)$.

${ }^{1} \mathrm{TEAC}=$ Trolox equivalent antioxidant capacity; ORAC $=$ oxygen radical antioxidant capacity; antioxidant activity was expressed as micromoles of Trolox equivalents per milligram of lyophilized sample ( $\mu \mathrm{mol}$ of TE/mg of LS). Values are expressed as means $\pm \mathrm{SD}(\mathrm{n}=3)$.

transport peptide fractions from the basolateral to the apical side. After $2 \mathrm{~h}$ of absorption, $\mathrm{PN}$ content was in the order CE-F1 $>$ CE-F2 $>$ CE-F4 $>$ CE-F3, which indicates that charge properties of peptide fractions can influence their transport efficiency, and that negatively charged peptide fractions can cross the intestinal epithelia more easily than positively charged ones.

\section{BA Assay}

The BA of peptide is usually influenced by many structural features, of which charge is an important one (Veber et al., 2002). The BA of peptide fractions by in vitro Caco-2 cell transepithelial absorption is shown in Figure 3. The PN contents of permeates of the 4 fractions varied from 0.73 to $1.05 \mu \mathrm{mol}$ of glycine equivalent $(P<0.05)$. The CE-F1 fraction showed the highest $\mathrm{BA}$ of $9.45 \pm 0.57 \%$, followed by CE-F2 and CE-F4. This result indicated that, compared with positively charged peptides, the negatively charged peptides have higher BA. Samaranayaka et al. (2010) reported that the $5.04 \%$ of Pacific hake fish protein hydrolysates and $2.80 \%$ of GI digest of fish protein hydrolysates could permeate the Caco-2 cell monolayer. The high BA of NCF may be due to 2 factors: (1) the negative charge might make peptides easier to transport across intestinal epithelium to the blood circulation, and (2) negatively charged peptide are more resistant to hydrolysis by peptidases.

\section{Changes in Antioxidant Activities During In Vitro GI Digestion and Caco-2 Cell Transport}

Figure 4 shows antioxidant activity by TEAC and ORAC assays of the 4 fractions after a 4 -h simulated GI digestion. The NCF digest showed higher TEAC and ORAC values than did the PCF digest, in agreement with results reported by $\mathrm{Ao}$ and $\mathrm{Li}$ (2013).

The GI digests of 4 fractions were applied to the Caco-2 cells. During the 2 -h transport, the TEAC val-
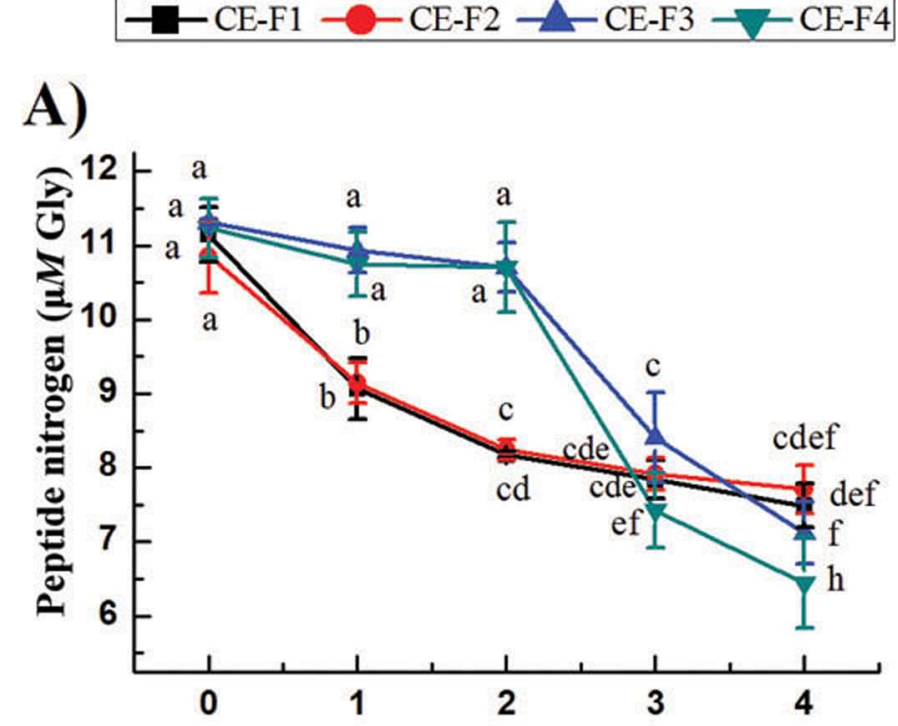

Time (h)

B)

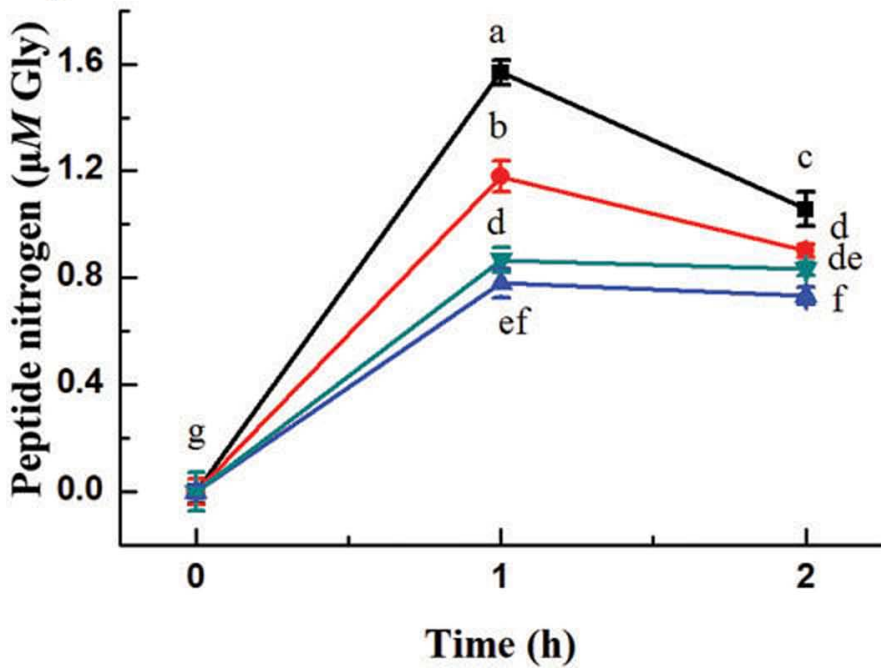

Figure 2. Changes in peptide nitrogen of the 4 peptide fractions (CE-F1 to CE-F4) during in vitro gastrointestinal digestion and absorption. The peptide fractions were applied to simulated gastrointestinal digestion (A) followed by Caco-2 cell absorption (B). Different letters in the same panel $(\mathrm{a}-\mathrm{h})$ denote statistically significant differences $(P<0.05)$. Values are expressed as means $\pm \mathrm{SD}(\mathrm{n}=3)$. Color version available online.

ues of 4 fractions (Figure 5A) increased significantly $(P<0.05)$. Moreover, $\mathrm{CE}-\mathrm{F} 1$ had the highest TEAC value, $394.56 \pm 9.29 \mu \mathrm{mol}$ of $\mathrm{TE} / \mathrm{mg}$ of $\mathrm{LS}$, and $\mathrm{CE}$ F4 had the lowest TEAC value, $190.62 \pm 5.46 \mu \mathrm{mol}$ of TE/mg of LS, at the end of the period. Figure $5 \mathrm{~B}$ showed that ORAC values increased $(P<0.05)$ for both NCF and PCF during Caco-2 cell permeation. However, NCF had higher ORAC values $(P<0.05)$ 


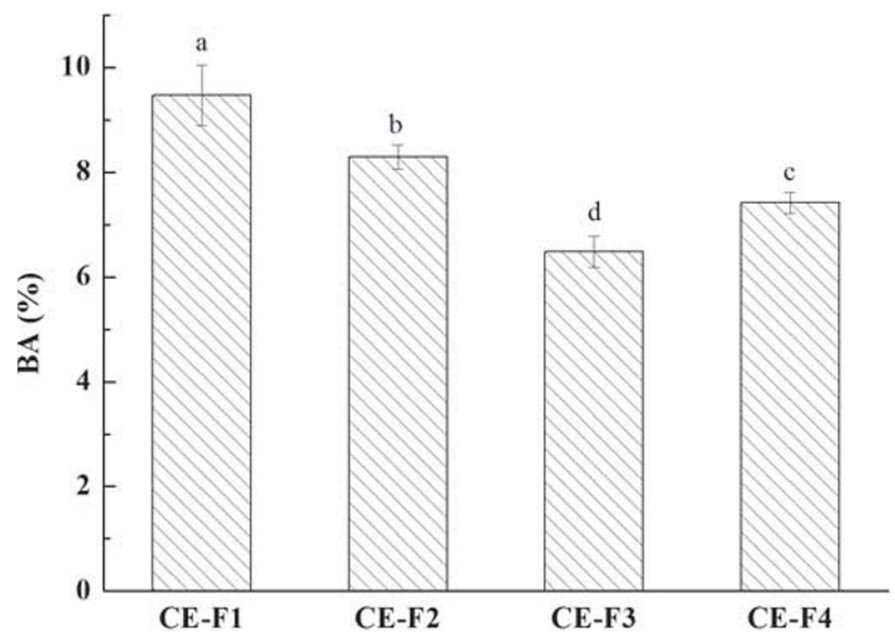

Figure 3. Bioavailability (BA) of negatively (CE-F1 and CE-F2) and positively charged (CE-F3 and CE-F4) peptide fractions separated by cation-exchange chromatography. Different letters $(\mathrm{a}-\mathrm{d})$ denote statistically significant differences $(P<0.05)$. Values are expressed as means $\pm \mathrm{SD}(\mathrm{n}=3)$. compared with PCF; we detected no significant difference between CE-F1 and CE- F2 $(P>0.05)$. In brief, at the end of Caco-2 cell transport, $\mathrm{NCF}$ exerted better antioxidant activity (TEAC and ORAC) than PCF. This may depend partly on their AA composition (Table 2). Saiga et al. (2003) separated the acidic fraction from porcine myofibrillar protein hydrolysates by using an ion exchange column and reported that acidic peptides exhibited higher antioxidant activity than the neutral or basic fractions.

\section{Cell Viability}

After human GI digestion and absorption, peptide permeates are thought to be bioavailable in vivo, which may directly contribute to their physiological efficacy (Fernández-García et al., 2009). Therefore, after GI digestion and absorption, the absorbates of 4 fractions were tested on oxidative HepG-2 cells to evaluate the cellular protection function.

The cytotoxicity of 4 permeates was tested by the trypan blue dye exclusion method, in which live cells with intact cell membranes can exclude the dye (Wi-

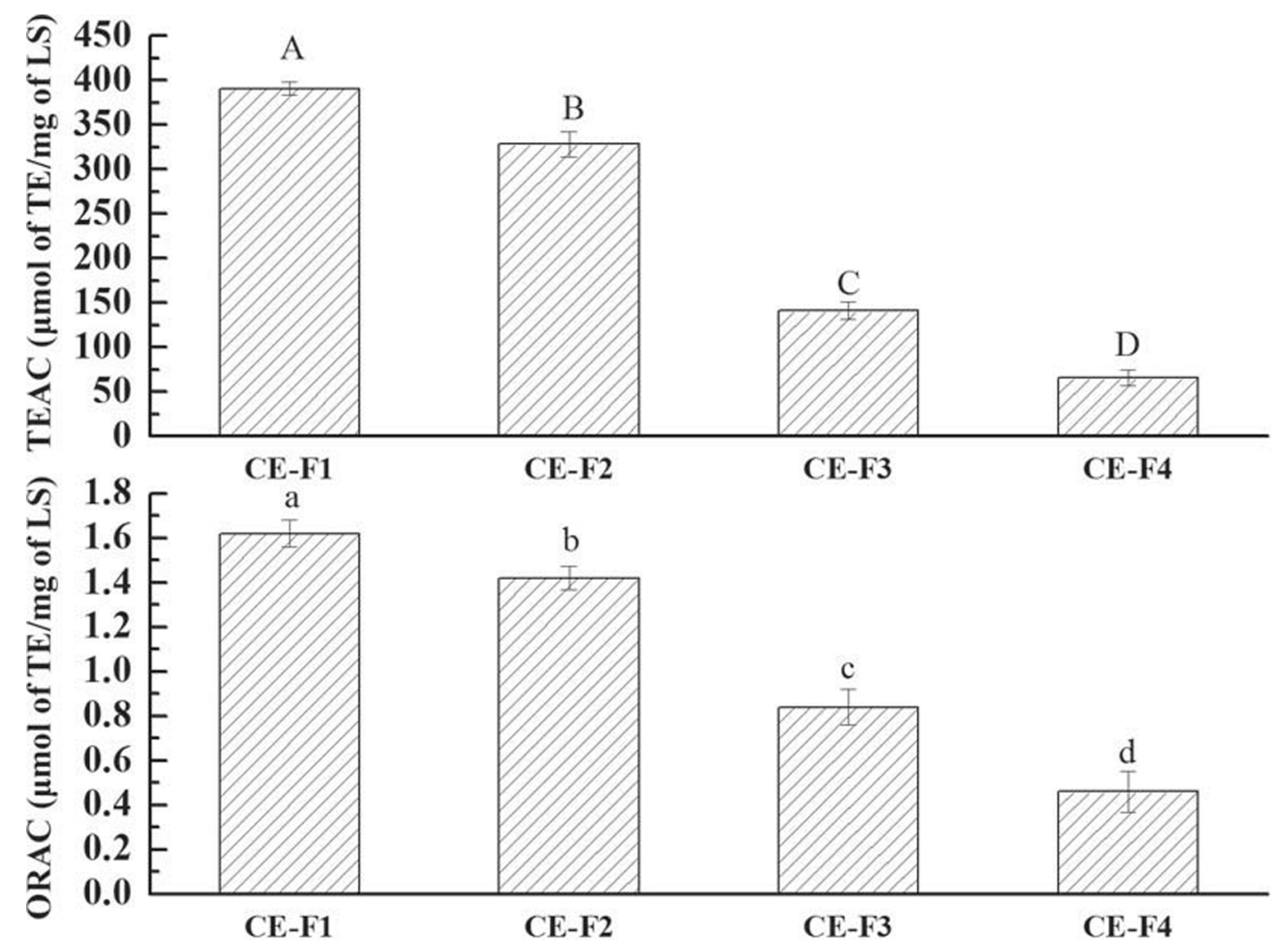

Figure 4. Antioxidant activities (TEAC = Trolox equivalent antioxidant capacity; ORAC = oxygen radical antioxidant capacity) of negatively (CE-F1 and CE-F2) and positively charged (CE-F3 and CE-F4) peptide fractions after $4 \mathrm{~h}$ simulated in vitro gastrointestinal digestion. Antioxidant activities were expressed as micromoles of Trolox equivalents per milligram of lyophilized sample ( $\mu \mathrm{mol}$ of TE/mg of LS). Different letters $(\mathrm{A}-\mathrm{D}$ or $\mathrm{a}-\mathrm{d})$ in the same panel denote statistically significant differences $(P<0.05)$. Values are expressed as means \pm SD $(\mathrm{n}=3)$. 

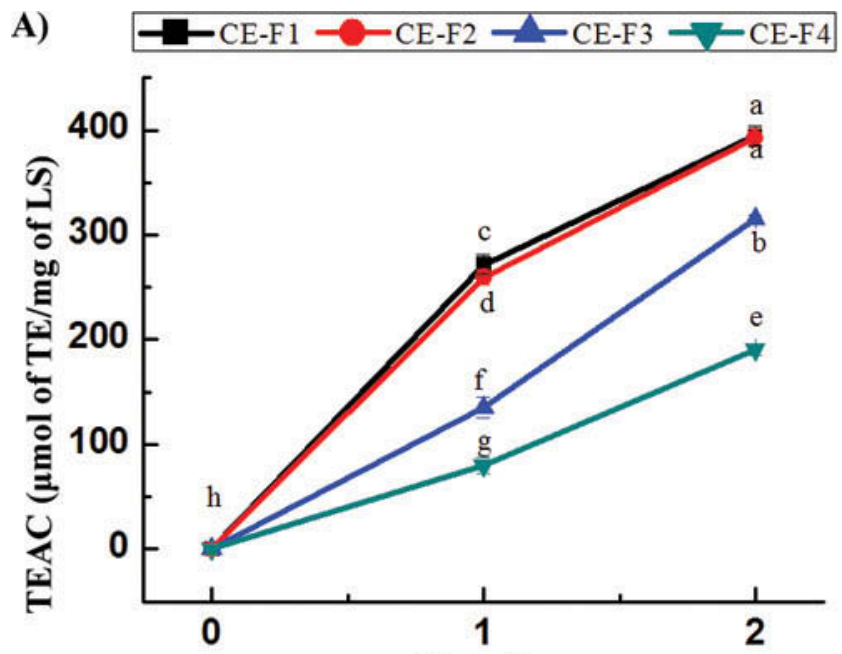

B)

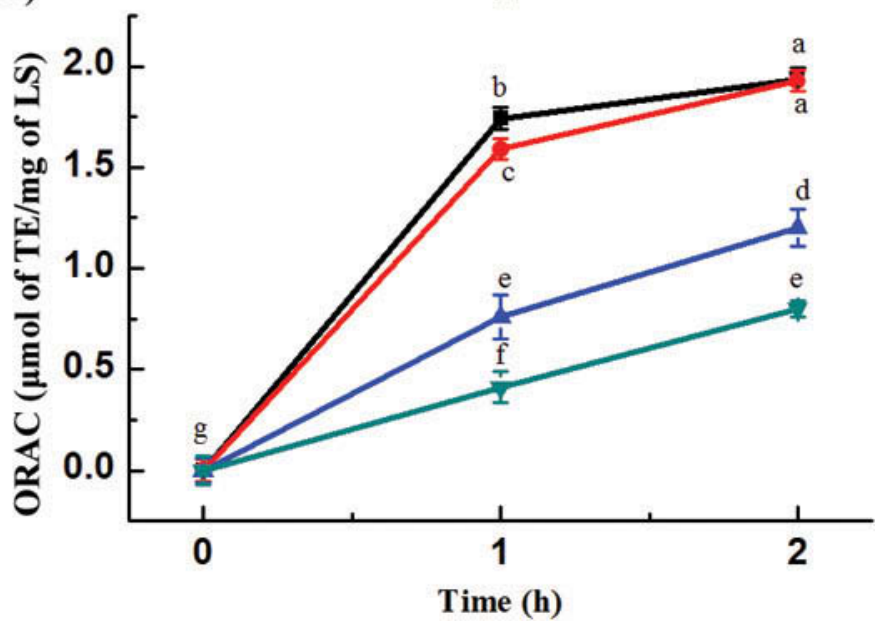

Figure 5. Changes in antioxidant activities by Trolox equivalent antioxidant capacity (TEAC; A) and oxygen radical antioxidant capacity (ORAC; B) of negatively (CE-F1 and CE-F2) and positively charged (CE-F3 and CE-F4) peptide fractions during Caco-2 cell absorption. Antioxidant activities were expressed as micromoles of Trolox equivalents per milligram of lyophilized sample ( $\mu$ mol of TE/ $\mathrm{mg}$ of LS). Different letters in the same panel $(\mathrm{a}-\mathrm{h})$ denote statistically significant differences $(P<0.05)$. Values are expressed as means $\pm \mathrm{SD}$ $(\mathrm{n}=3)$. Color version available online.

jeratne et al., 2005). Figure 6 shows that preincubation of cells with peptide permeates without oxidative stress did not impair cell viability, indicating that the 4 peptide fractions had no cytotoxic effect upon HepG2 cells. After treatment of HepG-2 cells with $50 \mu M$ $\mathrm{H}_{2} \mathrm{O}_{2}$ for $24 \mathrm{~h}$, cell viability was decreased $(P<0.05)$ compared with the control (23\%, cells incubated with complete medium). Hydrogen peroxide can directly damage DNA, lipids, and other macromolecules, which causes oxidative injury to cells (García-Nebot et al., 2011). However, pretreatment of cells with peptide permeates prevented the decline in cell viability (Figure 6). In particular, the permeate of CE-F1 increased HepG-2 cell viability by $20 \%$ compared with the $\mathrm{H}_{2} \mathrm{O}_{2}$ group, which was greater than the effect seen for the other 3 groups $(P<0.05)$. The 4 peptide permeates can modulate the deleterious effect produced by oxidative stress, and negatively charged peptide fractions have a greater protective effect against $\mathrm{H}_{2} \mathrm{O}_{2}$-induced cytotoxicity.

\section{Cytoprotection of Permeates Against $\mathrm{H}_{2} \mathrm{O}_{2}$-Induced Oxidative Stress in HepG-2 Cells}

In the defense against oxidative stress, an antioxidant enzyme network (CAT, SOD, GSH-Px) protects cells against oxidative stress (García-Nebot et al., 2011). To further illustrate the cytoprotection mechanism of 4 peptide permeates, we determined the activities of CAT, SOD, and GSH-Px in HepG-2 cells treated with peptide permeates or peptide permeates plus $\mathrm{H}_{2} \mathrm{O}_{2}$ (Table 3). Peroxide-induced oxidative stress caused a very significant decrease in the activity of CAT (an $80 \%$ decrease) compared with the control group $(P<0.01)$. Likewise, García-Nebot et al. (2011) and Katayama et al. (2007) reported a decrease in CAT activity after treating Caco-2 cells with oxidative stress. Following incubation with permeates only, the CE-F3 group showed a very significant increase (2-fold) in CAT activity compared with the control group $(P<0.01)$, whereas the other 3 groups did not show significant changes $(P>$ 0.05). However, following preincubation with peptide permeates before addition of $\mathrm{H}_{2} \mathrm{O}_{2}$, all groups showed a significant increase in CAT activity compared with the $\mathrm{H}_{2} \mathrm{O}_{2}$-treated group $(P<0.05)$. Moreover, CE-F2 and CE-F3 showed a significant increase (2.5-fold) in CAT activity $(P<0.01)$. This result might indicate that both NCF and PCF permeates can modulate CAT activity. Similarly, Phelan et al. (2009) observed an increase in CAT activity after treating Jurkat $\mathrm{T}$ cells with casein hydrolysates that were obtained by hydrolyzing commercial sodium caseinate with proteinases. It is interesting that CE-F3 could significantly elevate CAT activity whether HepG-2 cells were treated or not with $\mathrm{H}_{2} \mathrm{O}_{2}$. Rafikov et al. (2014) reported that endothelin-1 could stimulate CAT activity in endothelial cells via the phosphorylation of serine residues. We speculate that pretreatment with CE-F3 and its permeate might modulate CAT signaling cascades and upregulate the CAT gene in HepG-2 cells.

After exposure to $\mathrm{H}_{2} \mathrm{O}_{2}$, HepG-2 cells showed an increase in SOD activity $(P<0.05)$. Following treatment with NCF and PCF permeates only, SOD activity showed no significant difference compared with the control cells $(P>0.05)$. However, peptide permeate treatment followed by oxidative stress showed a significantly reduction in activity of SOD compared with the $\mathrm{H}_{2} \mathrm{O}_{2}$-treated group $(P<0.05)$. Thus, the 4 peptide 
Table 3. Effects of the 4 peptide fraction permeates (after simulated gastrointestinal digestion and absorption by Caco-2 cell monolayer) on catalase (CAT), superoxide dismutase (SOD), and glutathione peroxidase (GSH-Px) activities in $\mathrm{H}_{2} \mathrm{O}_{2}$-induced oxidative HepG-2 cells $^{1}$

\begin{tabular}{|c|c|c|c|}
\hline \multirow[b]{2}{*}{ Group $^{2,3}$} & \multicolumn{3}{|c|}{ Enzyme activity (U/mg of protein) } \\
\hline & CAT & SOD & GSH-Px \\
\hline Control & $2.17 \pm 0.43$ & $30.12 \pm 0.61$ & $38.11 \pm 4.32$ \\
\hline $\mathrm{CE}-\mathrm{F} 1$ & $1.92 \pm 0.81$ & $30.93 \pm 0.98$ & $37.39 \pm 7.42$ \\
\hline CE-F2 & $2.41 \pm 1.15$ & $30.86 \pm 0.82$ & $39.86 \pm 3.36$ \\
\hline CE-F3 & $4.26 \pm 0.35^{* *}$ & $29.91 \pm 1.02$ & $37.41 \pm 4.52$ \\
\hline CE-F4 & $2.77 \pm 1.10$ & $29.48 \pm 0.85$ & $38.22 \pm 1.87$ \\
\hline $\mathrm{H}_{2} \mathrm{O}_{2}$ & $0.43 \pm 0.34$ & $38.58 \pm 2.12$ & $36.31 \pm 4.83$ \\
\hline $\mathrm{CE}-\mathrm{F} 1+\mathrm{H}_{2} \mathrm{O}_{2}$ & $1.28 \pm 0.21 \dagger$ & $24.72 \pm 0.57 \dagger$ & $39.29 \pm 5.92$ \\
\hline $\mathrm{CE}-\mathrm{F} 2+\mathrm{H}_{2} \mathrm{O}_{2}$ & $5.28 \pm 0.58 \dagger \dagger$ & $21.66 \pm 0.35 \dagger$ & $36.82 \pm 5.55$ \\
\hline $\mathrm{CE}-\mathrm{F} 3+\mathrm{H}_{2} \mathrm{O}_{2}$ & $5.57 \pm 1.77 \dagger \dagger$ & $22.03 \pm 1.20 \dagger$ & $36.13 \pm 2.43$ \\
\hline $\mathrm{CE}-\mathrm{F} 4+\mathrm{H}_{2} \mathrm{O}_{2}$ & $2.01 \pm 0.98 \dagger$ & $24.82 \pm 0.56 \dagger$ & $37.96 \pm 7.66$ \\
\hline
\end{tabular}

${ }^{1}$ Values are expressed as means $\pm \mathrm{SD}(\mathrm{n}=6)$.

${ }^{2}$ Cell cultures exposed to culture medium were considered controls. Groups with only peptide permeates were compared with the control group: ${ }^{* *} P<0.01$ compared with the control group.

${ }^{3}$ Groups with both peptide permeates and $\mathrm{H}_{2} \mathrm{O}_{2}$ were compared with the $\mathrm{H}_{2} \mathrm{O}_{2}$ group: $\uparrow P<0.05$, $\uparrow \dagger P<0.01$ compared with the $\mathrm{H}_{2} \mathrm{O}_{2}$ group. permeates may prevent the increase in SOD activity induced by oxidative stress. Our result agreed with that of Alía et al. (2006), who treated HepG-2 cells with 100 $\mu M$ quercetin for $3 \mathrm{~h}$, followed by oxidative stress with $200 \mu M$ tertbutylhydroperoxide.

Activity of GSH-Px did not change $(P>0.05)$ under all tested conditions. The same observation was reported by Alía et al. (2006), who treated HepG-2 cells with 0.1 to $100 \mu M$ quercetin and rutin, followed by oxidative stress.

Pretreatment with permeates of 4 peptide fractions induced CAT activity and decreased SOD activity. We inferred that CAT might be the main enzyme involved in detoxification of oxidative damage. These permeates, at the cellular level, could scavenge the effect of free radicals. This result coincided in part with those by García-Nebot et al. (2011), who reported that caseinophosphopeptides protect cells against oxidative damage by increasing GSH content, inducing catalase enzyme activity, diminishing lipid peroxidation, and maintaining a correct cell cycle progression.

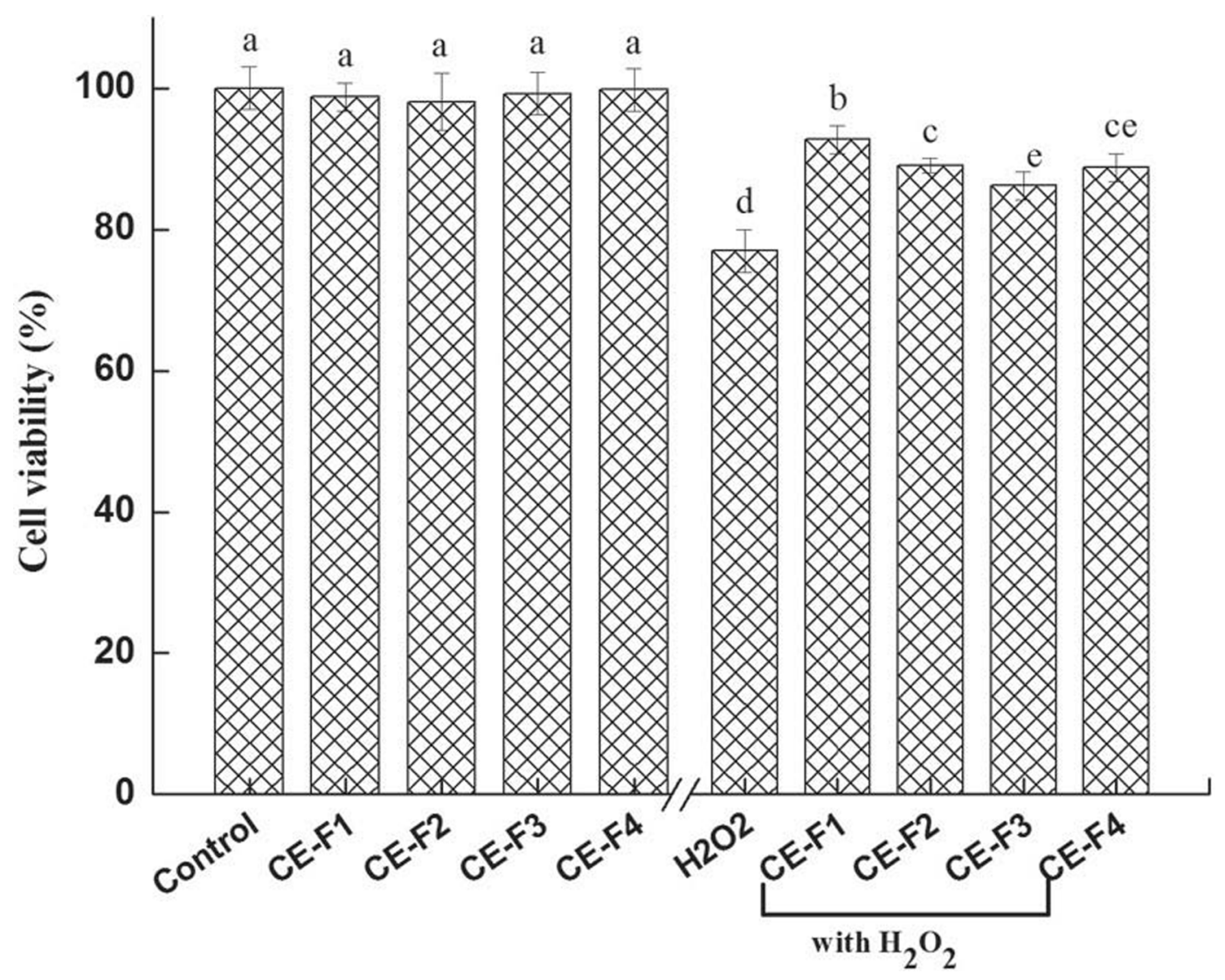

Figure 6. Effects of 4 peptide fraction permeates (CE-F1 to CE-F4; after simulated gastrointestinal digestion and cell absorption) on HepG-2 cell viability, with and without $\mathrm{H}_{2} \mathrm{O}_{2}$-induced oxidative stress. The cells were incubated with peptide permeates $(1 \mathrm{mg} / \mathrm{mL})$ for $24 \mathrm{~h}$ and then treated or not with $50 \mu \mathrm{M} \mathrm{H}_{2} \mathrm{O}_{2}$ for $12 \mathrm{~h}$. Cell cultures exposed to culture medium were considered as controls. Different letters denote statistically significant difference $(P<0.05)$. Values are expressed as means $\pm \mathrm{SD}(\mathrm{n}=6)$. 
Charge is an important feature that affects peptide bioavailability (Veber et al., 2002). In the present study, casein hydrolysates were separated into NCF and PCF using a cation-exchange column. To study the effect of peptide charge properties on bioavailability and antioxidant efficacy, simulated gastric juice, simulated intestinal juice, and Caco-2 cell monolayer were used to simulate digestion and absorption in vivo. Caco-2 cells undergo a process of differentiation under specific culture conditions, leading to the expression of several morphological and functional characteristics of the enterocyte, including the microvillus structure and of brush border enzymes in the apical membrane (Howell et al., 1992). It has been demonstrated that Caco- 2 cells express at least 8 aminopeptidases, including oligoaminopeptidase, aminopeptidase $\mathrm{N}$, and dipeptidylpeptidase IV (Zweibaum et al., 1984). Therefore, it is widely used as a model for peptide transepithelial transport studies (Shimizu et al., 1997; SienkiewiczSzlapka et al., 2009; Cakir-Kiefer et al., 2011).

When bioactive peptides are in the digestive tract, proteases may affect their biological activities by modifying their structure (Escudero et al., 2014). In the present study, NCF with a high content of acidic AA (Table 2) was resistant to intestinal digestion and unstable to gastric digestion. However, PCF was resistant to gastric digestion and unstable to intestinal digestion. At the end of GI digestion, NCF had higher PN than PCF. This result was in agreement with those of Ao and $\mathrm{Li}$ (2013), who indicated that positively charged fractions from casein hydrolysate showed lesser digestive stability than negatively charged fractions.

Moreover, NCF showed higher PN than PCF during transepithelial transport across Caco-2 monolayers. Chittchang et al. (2007) revealed that poly(D-glutamic acid) possesses high permeability across Caco-2 cell monolayers at $\mathrm{pH}$ 7.4. Rubas et al. $(1994,1995)$ reported that peptides with a net charge of -1 to -2 exhibit optimum permeability across the intestinal tissue. There are generally 3 mechanisms for transepithelial oligopeptide transport in intestinal tract (Miguel et al., 2008), among which the paracellular pathway is related to peptide charge properties. The junctional space in the paracellular pathway exhibits an electrostatic field with a negative net charge that may affect the paracellular flux of peptides due to charge-charge interactions (Shimizu et al., 1997). However, the most favorable charge for this pathway remains controversial. Knipp et al. (1995) and Okumu et al. (1995) studied the transport of several hexapeptides and pentapeptides in Caco-2 cell monolayers, and transport efficiency did not show any discrimination based on differences in charge. Ho et al. (1990) found that cationic poly(D-lysine) was localized predominantly on the apical membrane surface of all intestinal epithelia and had very low permeability. In the present study, the paracellular pathway was most likely involved in the transport of $\mathrm{NCF}$ and PCF. In addition, $\mathrm{NCF}$ may show high permeability across Caco-2 monolayers.

\section{CONCLUSIONS}

Casein peptide permeates showed good antioxidative efficacy and cytoprotective effects against $\mathrm{H}_{2} \mathrm{O}_{2}$-induce oxidative stress in HepG-2 cells. In particular, peptide charge was well correlated with efficacy and bioavailability. Negatively charged peptides showed greater bioavailability than positively charged peptides, and their permeates exhibited excellent cytoprotective effects against $\mathrm{H}_{2} \mathrm{O}_{2}$-induced oxidative stress by preserving cell viability. Industrial-scale technologies suitable for commercial production of bioactive milk peptides have been developed. The main technique to separate negatively charged peptides is easy to carry out. The present research supports the use of negatively charged peptides derived from casein as natural antioxidants in a dietary food matrix. However, further studies using in vivo animal models and human clinical trials are necessary before consumer use.

\section{ACKNOWLEDGMENTS}

This research was supported by National Natural Science Foundation of China (NSFC, No. 31271846, Beijing, China) and the Program for New Century Excellent Talents in the University of Ministry of Education of China (Grant No. 2010JS078, Beijing, China).

\section{REFERENCES}

Agudelo, R. A., S. F. Gauthier, Y. Pouliot, J. Marin, and L. Savoie. 2004. Kinetics of peptide fraction release during in vitro digestion of casein. J. Sci. Food Agric. 84:325-332.

Alía, M., R. Mateos, S. Ramos, E. Lecumberri, L. Bravo, and L. Goya 2006. Influence of quercetin and rutin on growth and antioxidant defense system of a human hepatoma cell line (HepG2). Eur. J. Nutr. 45:19-28.

Ao, J., and B. Li. 2013. Stability and antioxidative activities of casein peptide fractions during simulated gastrointestinal digestion in vitro: Charge properties of peptides affect digestive stability. Food Res. Int. 52:334-341.

Binker, M. G., D. Richards, H. Y. Gaisano, and L. I. Cosen-Binker. 2015. ER stress-associated CTRC mutants decrease stimulated pancreatic zymogen secretion through SIRT2-mediated microtubule dysregulation. Biochem. Biophys. Res. Commun. 463:329 335 .

Bodó, A., E. Bakos, F. Szeri, A. Varadi, and B. Sarkadi. 2003. The role of multidrug transporters in drug availability, metabolism and toxicity. Toxicol. Lett. 140-141:133-143.

Burrell, M. M., ed. 1993. Enzymes of Molecular Biology. Humana Press, Totowa, NJ.

Cakir-Kiefer, C., L. Miclo, F. Balandras, A. Dary, C. Soligot, and Y. Le Roux. 2011. Transport across Caco-2 cell monolayer and sensitivity to hydrolysis of two anxiolytic peptides from $\alpha_{S^{-}}$Casein, 
$\alpha$-Casozepine, and $\alpha_{\mathrm{S1} 1}$ Casein-(f91-97): Effect of bile salts. J. Agric. Food Chem. 59:11956-11965.

Cardillo, G., L. Gentilucci, A. Tolomelli, M. Calienni, A. R. Qasem, and S. Spampinato. 2003. Stability against enzymatic hydrolysis of endomorphin-1 analogues containing beta-proline. Org. Biomol. Chem. 1:1498-1502.

Chen, J. H., S. Xue, S. Li, Z. L. Wang, H. Yang, W. Wang, D. Song, X. Zhou, and C. Chen. 2012. Oxidant damage in Kashin-Beck disease and a rat Kashin-Beck disease model by employing T-2 toxin treatment under selenium deficient conditions. J. Orthop. Res. 30:1229-1237.

Chen, M., and B. Li. 2012. The effect of molecular weights on the survivability of casein-derived antioxidant peptides after the simulated gastrointestinal digestion. Innov. Food. Sci. Emerg. 16:341-348.

Chittchang, M., A. K. Mitra, and T. P. Johnston. 2007. Interplay of secondary structure and charge on the diffusion of a polypeptide through negatively charged aqueous pores. Pharm. Res. 24:502511.

Cinq-Mars, C. D., C. Hu, D. D. Kitts, and E. C. Y. Li-Chan. 2008. Investigation into inhibitor type and mode, simulated gastrointestinal digestion, and cell transport of the angiotensin I-converting enzyme-inhibitory peptides in Pacific hake (Merluccius productus) fillet hydrolysate. J. Agric. Food Chem. 56:410-419.

Contreras, M. M., R. Carrón, M. J. Montero, M. Ramos, and I. Recio. 2009. Novel casein-derived peptides with antihypertensive activity Int. Dairy J. 19:566-573.

Dávalos, A., C. Gómez-Cordovés, and B. Bartolomé. 2004. Extending applicability of the oxygen radical absorbance capacity (ORACFluorescein) assay. J. Agric. Food Chem. 52:48-54.

De Gobba, C., G. Tompa, and J. Otte. 2014. Bioactive peptides from caseins released by cold active proteolytic enzymes from Arsukibacterium ikkense. Food Chem. 165:205-215.

Escudero, E., L. Mora, and F. Toldrá. 2014. Stability of ACE inhibitory ham peptides against heat treatment and in vitro digestion. Food Chem. 161:305-311.

Fernández-García, E., I. Carvajal-Lérida, and A. Pérez-Gálvez. 2009 In vitro bioaccessibility assessment as a prediction tool of nutritional efficiency. Nutr. Res. 29:751-760.

García-Nebot, M. J., A. Cilla, A. Alegría, and R. Barberá. 2011. Caseinophosphopeptides exert partial and site-specific cytoprotection against $\mathrm{H}_{2} \mathrm{O}_{2}$-induced oxidative stress in Caco-2 cells. Food Chem. 129:1495-1503.

Ho, N. F. H., J. S. Day, C. L. Barsuhn, P. S. Burton, and T. J. Raub, 1990. Biophysical model approaches to mechanistic transepithelial studies of peptides. J. Control. Release 11:3-24.

Howell, S., A. J. Kenny, and A. J. Turner. 1992. A survey of membrane peptidases in 2 human colonic cell-lines, Caco-2 and Ht-29. Biochem. J. 284:595-601.

Jiang, L. P., B. Wang, B. Li, C. Wang, and Y. K. Luo. 2014. Preparation and identification of peptides and their zinc complexes with antimicrobial activities from silver carp (Hypophthalmichthys molitrix) protein hydrolysates. Food Res. Int. 64:91-98.

Katayama, S., S. Ishikawa, M. Z. Fan, and Y. Mine. 2007. Oligophosphopeptides derived from egg yolk phosvitin up-regulate gammaglutamylcysteine synthetase and antioxidant enzymes against oxidative stress in Caco-2 cells. J. Agric. Food Chem. 55:2829-2835.

Kim, G., H. Jang, and C. Kim. 2007. Antioxidant capacity of caseinophosphopeptides prepared from sodium caseinate using alcalase. Food Chem. 104:1359-1365.

Kitts, D. D. 2005. Antioxidant properties of casein-phosphopeptides. Trends Food Sci. Technol. 16:549-554.

Knipp, G. T., D. G. Vander Velde, T. J. Siahaan, and R. T. Borchardt. 1995. The effect of solution conformation and charge on the paracellular permeability of model pentapeptides across Caco-2 cell monolayers. Pharm. Res. 12:S-303.

Liceaga-Gesualdo, A. M., and E. C. Y. Li-Chan. 1999. Functional properties of fish protein hydrolysate from herring (Clupea harengus). J. Food Sci. 64:1000-1004.

Malinowski, J., M. Klempt, I. Clawin-Rädecker, P. Chr. Lorenzen, and H. Meisel. 2014. Identification of a NFkB inhibitory peptide from tryptic $\beta$-casein hydrolysate. Food Chem. 165:129-133.
Miguel, M., A. Dávalos, M. A. Manso, G. de la Peña, M. A. Lasunción, and R. López-Fandiño. 2008. Transepithelial transport across Caco-2 cell monolayers of antihypertensive egg-derived peptides. PepT1-mediated flux of Tyr-Pro-Ile. Mol. Nutr. Food Res. 52:1507-1513

Mizuno, S., S. Nishimura, K. Matsuura, T. Gotou, and N. Yamamoto. 2004. Release of short and proline-rich antihypertensive peptides from casein hydrolysate with an Aspergillus oryzae protease. J. Dairy Sci. 87:3183-3188.

Okumu, F. W., G. M. Pauletti, D. G. Vander Velde, T. J. Siahaan, and R. T. Borchardt. 1995. The effect of charge and conformation on the permeability of a hexapeptide across monolayers of a cultured human intestinal epithelial cell (Caco-2 cells). Pharm. Res. 12:S-302

Orsini Delgado, M. C., V. A. Tironi, and M. Cristina Añón. 2011. Antioxidant activity of amaranth protein or their hydrolysates under simulated gastrointestinal digestion. Food Sci. Technol. (Campinas) 44:1752-1760

Phelan, M., S. A. Aherne-Bruce, D. O'Sullivan, R. J. FitzGerald, and N. M. O'Brien. 2009. Potential bioactive effects of casein hydrolysates on human cultured cells. Int. Dairy J. 19:279-285.

Picariello, G., P. Ferranti, O. Fierro, G. Mamone, S. Caira, A. Di Luccia, S. Monica, and F. Addeo. 2010. Peptides surviving the simulated gastrointestinal digestion of milk proteins: biological and toxicological implications. J. Chromatogr. B Analyt. Technol. Biomed. Life Sci. 878:295-308.

Rafikov, R., S. Kumar, S. Aggarwal, Y. Hou, A. Kangath, D. Pardo, J. R. Fineman, and S. M. Black. 2014. Endothelin-1 stimulates catalase activity through the $\mathrm{PKC} \delta$-mediated phosphorylation of serine 167. Free Radic. Biol. Med. 67:255-264.

Regazzo, D., D. Mollé, G. Gabai, D. Tomé, D. Dupont, J. Leonil, and R. Boutrou. 2010. The (193-209) 17-residues peptide of bovine $\beta$-casein is transported through Caco- 2 monolayer. Mol. Nutr. Food Res. 54:1428-1435.

Rubas, W., M. Cromwell, T. Gadek, D. Narindray, and R. Mrsny. 1994. Structural elements which govern the resistance of intestinal tissues to compound transport. Mater. Res. Soc. Symp. Proc. 331:179-185.

Rubas, W., J. Villagran, M. Cromwell, A. McLeod, J. Wassenberg, and R. Mrsny. 1995. Correlation of solute flux across Caco-2 monolayers and colonic tissue in vitro. S.T.P. Pharma Sci. 5:93-97.

Saiga, A., S. Tanabe, and T. Nishimura. 2003. Antioxidant activity of peptides obtained from porcine myofibrillar proteins by protease treatment. J. Agric. Food Chem. 51:3661-3667.

Samaranayaka, A. G. P., D. D. Kitts, and E. C. Y. Li-Chan. 2010 Antioxidative and angiotensin-I-converting enzyme inhibitory potential of a pacific hake (Merluccius productus) fish protein hydrolysate subjected to simulated gastrointestinal digestion and Caco-2 cell permeation. J. Agric. Food Chem. 58:1535-1542.

Sannaveerappa, T., S. Westlund, A. S. Sandberg, and I. Undeland. 2007. Changes in the antioxidative property of herring (Clupea harengus) press juice during a simulated gastrointestinal digestion. J. Agric. Food Chem. 55:10977-10985.

Sarmadi, B. H., and A. Ismail. 2010. Antioxidative peptides from food proteins: A review. Peptides 31:1949-1956.

Savoie, L., R. A. Agudelo, S. F. Gauthier, J. Marin, and Y. Pouliot. 2005. In vitro determination of the release kinetics of peptides and free amino acids during the digestion of food proteins. J. AOAC Int. 88:935-948.

Schwab, M., M. Eichelbaum, and M. F. Fromm. 2003. Genetic polymorphisms of the human MDR1 drug transporter. Annu. Rev. Pharmacol. Toxicol. 43:285-307.

Shimizu, M., M. Tsunogai, and S. Arai. 1997. Transepithelial transport of oligopeptides in the human intestinal cell, Caco-2. Peptides 18:681-687.

Sienkiewicz-Szlapka, E., B. Jarmolowska, S. Krawczuk, E. Kostyra, H. Kostyra, and K. Bielikowicz. 2009. Transport of bovine milkderived opioid peptides across a Caco-2 monolayer. Int. Dairy J. 19:252-257.

Silva, S. V., and F. X. Malcata. 2005. Caseins as source of bioactive peptides. Int. Dairy J. 15:1-15. 
Tagliazucchi, D., E. Verzelloni, and A. Conte. 2010. Effect of dietary melanoidins on lipid peroxidation during simulated gastric digestion: their possible role in the prevention of oxidative damage. J. Agric. Food Chem. 58:2513-2519.

Veber, D. F., S. R. Johnson, H. Y. Cheng, B. R. Smith, K. W. Ward, and K. D. Kopple. 2002. Molecular properties that influence the oral bioavailability of drug candidates. J. Med. Chem. 45:26152623.

Vermeirssen, V., B. Deplancke, K. A. Tappenden, J. Van Camp, H. R. Gaskins, and W. Verstraete. 2002. Intestinal transport of the lactokinin Ala-Leu-Pro-Met-His-Ile-Arg through a Caco-2 Bbe monolayer. J. Pept. Sci. 8:95-100.

Vij, R., S. Reddi, S. Kapila, and R. Kapila. 2016. Transepithelial transport of milk derived bioactive peptide VLPVPQK. Food Chem. 190:681-688.

Wijeratne, S. S. K., S. L. Cuppett, and V. Schlegel. 2005. Hydrogen peroxide induced oxidative stress damage and antioxidant enzyme response in Caco-2 human colon cells. J. Agric. Food Chem. $53: 8768-8774$.
Xie, N. N., C. Wang, J. Ao, and B. Li. 2013. Non-gastrointestinal-hydrolysis enhances bioavailability and antioxidant efficacy of casein as compared with its in vitro gastrointestinal digest. Food Res. Int. 51:114-122.

Yang, C. F., H. M. Shen, and C. N. Ong. 1999. Protective effect of ebselen against hydrogen peroxide-induced cytotoxicity and DNA damage in HepG2 cells. Biochem. Pharmacol. 57:273-279.

You, L., M. Zhao, J. M. Regenstein, and J. Ren. 2010. Changes in the antioxidant activity of loach (Misgurnus anguillicaudatus) protein hydrolysates during a simulated gastrointestinal digestion. Food Chem. 120:810-816.

Zulueta, A., M. J. Esteve, and A. Frígola. 2009. ORAC and TEAC assays comparison to measure the antioxidant capacity of food products. Food Chem. 114:310-316.

Zweibaum, A., H. P. Hauri, E. Sterchi, I. Chantret, K. Haffen, J. Bamat, and B. Sordat. 1984. Immunohistological evidence, obtained with monoclonal antibodies, of small intestinal brush border hydrolases in human colon cancers and foetal colons. Int. J. Cancer 34:591-598. 